\title{
Defining Communication Problems in Stakeholder Relations Based on Stakeholder Theory
}

\section{Mengurai Masalah Komunikasi dalam Stakeholder Relations Berbasis Stakeholder Theory}

\author{
Helpris Estaswara \\ Fakultas Ilmu Komunikasi, Universitas Pancasila, Jl. Srengseng Sawah, Jagakarsa, \\ Jakarta Selatan 12640 \\ E-mail: the.estaswara@yahoo.com
}

\begin{abstract}
Relationship with stakeholders has been widely seen as a communication phenomenon. Indeed, communication has long played an essential role in stakeholder theory. This study analyzed stakeholder relations in the communication discipline, which still left a room for review, based on stakeholder theory in the context of company management. Specifically, this study focused on both concepts in stakeholder relations, which was studied in communication science, and stakeholder theory, which was grounded on business ethics and strategic management. The concepts were analyzed using a social-oriented framework, and the aim was to disentangle and make evident the communication problems in this issue. The study used a literature review, to map the body of knowledge, and a qualitative approach based on a multidisciplinary perspective. This study recommended that stakeholder relations be a communication discipline, and it should examine stakeholders based on two interrelated analyses, namely normative and strategic. Stakeholder relations should focus on normativeethical studies, which were rooted in idealism. The strategic-operative aspects, which originated from realism, by contrast, could be delegated to other disciplines, such as public relations, organizational communication, corporate communication, strategic communication, to communication management.
\end{abstract}

Keywords: Communication discipline; Stakeholder Theory; Stakeholder Relations

\begin{abstract}
Abstrak
Hubungan dengan stakeholder sudah banyak dipandang sebagai gejala komunikasi. Bahkan, ilmu komunikasi diposisikan sebagai elemen penting dalam stakeholder theory. Artikel ini bertujuan mengurai masalah stakeholder relations dalam ilmu komunikasi yang masih menyisakan ruang untuk dikaji berdasarkan stakeholder theory dalam konteks pengelolaan perusahaan. Penelitian ini menggunakan literatur review untuk memetakan body of knowledge dengan pendekatan kualitatif yang multi-disipliner. Artikel ini menganalisis konsep-konsep stakeholder relations yang selama ini dipelajari dalam disiplin komunikasi dengan stakeholder theory yang berbasis business ethics dan strategic management dalam kerangka social-oriented guna mengurai masalah komunikasi. Hasilnya, tulisan ini merekomendasikan stakeholder relations sebagai disiplin ilmu komunikasi yang mengkaji stakeholder dengan dua penampang analisis (normatif-strategis) yang saling terkait. Paling tidak fokus pada kajian yang bersifat normatif-etis dengan berlandaskan aliran idealis. Sedangkan aspek strategis-operatif diserahkan pada ilmu lain, seperti public relations, strategic communication, corporate communication, organisational communication, maupun communication management.
\end{abstract}

Kata Kunci: Disiplin Komunikasi; Stakeholder Theory; Stakeholder Relations 


\section{Introduction}

As talking about theory in general, the stakeholder theory is complicated and demanding. The building blocks of the theory are not only sophisticated but also diverse in terms of perspectives (Donaldson \& Preston, 2005; Friedman \& Miles, 2002). It stemmed from studies in strategic management and business ethics before academically and practically growing in the 1980s. The publication of Strategic Management: A Stakeholder Approach" (1984) by Freeman was the pivotal breakthrough that made the discourse start to develop scientifically. Since that time, many academic publications, ranging from scientific journals to books, began to discuss stakeholder theory from different perspectives and approaches.

However, as this theory has not developed yet, as other theories at the beginning of the development, discussion on the pros and cons seem to be no end. The central discussion rotates in how this theory views and grasps the meaning of stakeholders, especially concerning its relationship with broader organizations, whether profit, nonprofit, or government) (Donaldson \& Preston, 1995; Friedman \& Miles 2002). Another vital discussion is the status of the scientific explanation of stakeholders itself. Many critics argued that stakeholder is only a concept and not a theory, and thus doubting the sufficiency. For them, stakeholder studies are merely a part of strategic management, and, therefore, any attempts to provide meaning to this subject is futile. As described by Freeman and other thinkers (Freeman et al., 2010:83-84):

Although the stakeholder approach to strategic management has influenced thinking in the field, there are numerous interpretations of it, the results of which are that it sometimes still struggles for acceptance among mainstream strategic management scholars. But, more likely from the view of many strategic management scholars that stakeholder theory is a part of the social responsibility literature and not central to strategic management theory. One probable cause of this reluctance is that many stakeholder theorists have refused to accept the 'purely scientific' approach that affects much of strategic management.

On the other hand, stakeholder theory's proponents believed that the conceptualization of the term stakeholder, which has long been theorized, has been legitimate to be a theory. The reason is that the scientific explanation in the stakeholder theory has met the requirements of the theory. Given that, these scientists openly alleged that the purpose of rejecting the stakeholder theory is its effect in transforming many aspects of strategic management so that it is not positivist anymore (standardization and formalization) but postmodernists/post-positivist.

Freeman (2004) contended that there is no single stakeholder theory. The stakeholder theory consists of many genres (including isms, approaches, or types), although those varied genres should still be possible to combine (collaborate and synergize) with other business theories and ethics to expand and deepen the analysis on companies in managing stakeholders' interests. Until now, the process of theorizing the stakeholder theory is still performed by numerous academicians throughout the world with different philosophies, approaches, and theories.

In general, the stakeholder theory focuses on business, ethics, and combination between them, whether in terms of pragmatism or formalism. Realism and idealism then become prominent camps within this discourse (Friedman \& Miles, 2006). While the 
former focus on practical consequences, which is very contextual regarding company behavior or managerial decisions, the latter pays more heed on ethical and normative (moral) issues or guide values, moral knowledge, and awareness that act as the basis evaluator of behavior.

Those two sides originate from different philosophies. The first side is grounded on realism principles believing that reality is reducible to the observable, or anything perceived by senses, and the measurable. This theory, thus, gives more space for strategic action. By contrast, the second side is founded on idealism and thus differentiating between the real and the actual. While for realists, what is real is what is actual, for idealists, what is real is what is in the human minds and their determination that relates to spirit and hopes. Norms, values, and ethics, therefore, are prioritized by the idealists as the ideal basis for companies to execute a decision. The explanation indicates that although there are numerous ideological and nomological differences on stakeholder theory, generally it can be simplified into two camps: a camp that prioritizes values spectrum (normative-ethical) that should be adhered by the company, and, a camp that emphasizes actions (descriptive-instrumental) in managing stakeholders relations.

The idealist stakeholder theory is typically called the normative stakeholder theory because it studies the guidance for the ethical action in company management. The primary maxim of this theory is: "do (not) this because it is the right (wrong) thing to do." On the other hand, the realist side is commonly called instrumental stakeholder theory as it analyzes stakeholder relations and its association with the company's objectives. The underlying maxim of this theory is: "if you want to achieve (avoid) results: $\mathrm{X}, \mathrm{Y}, \mathrm{Z}$, then adopt (do not adopt) principles and practices A, B, and C." Instrumental theory studies how far the management should consider different stakeholder's interests for achieving company aims. For that reason, this study is considered identic to strategic management.

Table 1: Differences Between Normative and Instrumental Stakeholder Theory

\begin{tabular}{|c|c|}
\hline $\begin{array}{c}\text { TYPE OF STAKEHOLDER } \\
\text { THEORY }\end{array}$ & DESCRIPTION \\
\hline \multirow{3}{*}{$\begin{array}{l}\text { Normative Stakeholder Theory } \\
\text { (Normative-ethical theory) }\end{array}$} & $\begin{array}{l}\text { Basic Notion: companies should relate to } \\
\text { stakeholders based on universal ethical values } \\
\text { (morality). }\end{array}$ \\
\hline & $\begin{array}{l}\text { Theoretical foundation: Social contract theory; } \\
\text { discourse ethics (Habermas); categorical imperative } \\
\text { (Kant): natural environment, feminist theory. }\end{array}$ \\
\hline & Philosophical ism: Idealism \\
\hline \multirow{3}{*}{$\begin{array}{l}\text { Instrumental Stakeholder Theory } \\
\text { (Strategic-operational theory) }\end{array}$} & $\begin{array}{l}\text { Basic notion: companies should relate to } \\
\text { stakeholders effectively and efficiently to realize } \\
\text { company objectives. }\end{array}$ \\
\hline & $\begin{array}{l}\text { Theoretical foundation: Strategic management } \\
\text { theory: network theory }\end{array}$ \\
\hline & Philosophical ism: realism \\
\hline
\end{tabular}

source: researcher's summary

With that in mind, a question arises: what is the position of communication science in the stakeholder study? Company relationship with stakeholder has long been 
considered as a communication phenomenon. Many thinkers in the stakeholder theory even posit communication science as an essential element. However, many communication scientists have not reached a consensus regarding this topic. Many studies on stakeholder theory within the communication perspective still make a distinction between "strategic-operative," or strategy management that is more tactical and operational, and normative-ethical (ethics and morality), although, for the latter, the gesture is more for lips service.

Owing to the problems mentioned, the article aims to analyze stakeholder relationships in communication science. There was still an open room to be reviewed using stakeholder theory in the context of company management. This research was a holistic review, and it applied multidisciplinary perspectives. The reason for using this perspective was to map the background of stakeholder theory and the related theory and delineate the essential issues that should be paid heed by academicians in this field.

\section{Methodology}

This research was a literature review. According to Hart (2018), a literature review is an essential scientific work to reveal what has been understood in the body of knowledge, as well as analyzing that structure to yield new understandings (Denney \& Tewksbury, 2012; Arshed \& Danson, 2015). In this research, that method was employed to intensify studies about stakeholders, fill the gap of multidiscipline perspectives, and giving new ideas for further research and development (Denney \& Tewksbury, 2012; Creswell, 2014; Marshall \& Rossman, 2015).

This research was qualitative, and it used a holistic approach to investigate stakeholder relations that are developed from stakeholder theories. This research also investigated communication disciplines that are associated with stakeholder relations, such as public relations, corporate communication, to stakeholder engagement (Denney $\&$ Tewksbury, 2012). The data was collected from scholarly non-empirical articles and essays (scientific journal), and it was retrieved from various relevant sources and textbooks (Denney \& Tewksbury, 2012).

\section{Results and discussion \\ Stakeholder Relations}

Before explaining the communication problems in stakeholder relations, it is vital to define the meaning of the stakeholder itself. A stakeholder is any non-profit organization and individuals, whether within or outside the organization, that significantly are capable of affecting or being affected by company activities. There are fundamental conceptual differences between stakeholders, stakeholder theory, and stakeholder relations. Stakeholders are the object-matter that is analyzed from different disciplines, including communication science and business management, and perspectives, such as schools of thought. It is different from the stakeholder theory that uses a mixed study between business ethics and strategic management. Stakeholder theory will always analyze companies and their stakeholder management, both normatively and ethically (Donaldson \& Preston, 1995; Friedman \& Miles, 2006).

Stakeholder relations, on the other hand, is more about relationship management with the stakeholders. Since the focus of stakeholder relations is relationship management, communication becomes one of the most vital elements (Mohr et al., 1996; Duncan \& Moriarty, 1998; Andersen, 2001; Sharma et al., 2001; Hutchinson et 
al., 2011). Stakeholder relations, therefore, is communication management between the company and stakeholders. Occasionally, this study is also named the company engagement or stakeholder communication (Bourne, 2015).

Stakeholder relations are never separated from stakeholder theory. Stakeholder theory is the conceptual basis to not only decide who, why, and how a company is associated with the stakeholder in the context of company management and achieving the objectives but also apply normative-ethical principles (Donaldson \& Preston, 1995; Phillips, 2003; Friedman \& Miles, 2002; 2006; Carrol \& Buchholtz, 2014). Because stakeholder theory is a combination between strategic management and business ethics (Friedman \& Miles, 2006), this theory can be categorized into a normative theory, which provides the ethical underpinnings of both company and stakeholder management (Donaldson \& Preston, 1995).

However, stakeholder theory can also be categorized as a strategic theory, which provides the basis for managerial practice. It is performed through the process of stakeholder interest management, and the purpose is for making harmonious relations between them. It is the reason the strategic theory is also called instrumental theory, which mostly take its inspiration from management, strategic planning, macroeconomy, politics, and business ethics, as it studies the planning, operation, and decision making strategy of stakeholder management (Jones, 1995; Freeman, 1984; Mitchell, Agle \& Wood, 1997; Friedman \& Miles, 2006).

Furthermore, the relationship in the stakeholder is en seen as a communication phenomenon. Even some thinkers of stakeholder theory posit communication science as an important element. For example, by suggesting external relation to public relations, Freeman (1984) made the public relations position central in the study of stakeholder relations. Indeed, he contended that customer relations, which put communication as the main principle, is the task of marketing.

It is in agreement with Duncan \& Moriarty (1998) that argued that customer relations are highly correlated with communication science in both IMC (Integrated Marketing Communications) and brand relations (Estaswara, 2011a, 2011b, 2015, 2016). Marketing communication thus also plays a significant element in stakeholder relations. This concept later is criticized by Grunig by exerting excellence theory in public relations. For him, if public relations fuse with the function of marketing or other functions in the company, it will deprive its unique and essential role in strategic management and, therefore, in the company's decision-making process. Public relations, then, is one of the central aspects of strategic management that relate to stakeholder relation.

As for communication's role in stakeholder discipline, Friedman and Miles (2006) asserted that the purpose of communication is significant to realize stakeholder satisfaction. This notion is identical with Strong, Ringer, and Taylor (2001) that believed that the quality of stakeholder satisfaction is mostly determined by communication factors, such as timeliness of communication, honesty, and completeness of the information. Likewise, Zöller (1999) recommended dialog as a form of two-way communication with stakeholders.

In addition, an attempt to involve communication science in the stakeholder theory is also expressed by Paul (2014). He argued that stakeholder theory could take advantage of thought in communication science, notably regarding the theory of media system dependency (MSD) and communication infrastructure theory (CIT). The main idea of the theories is that each stakeholder has different interests. Against that 
background, Paul stated that in managing different stakeholder interests, an interactive communication process between the companies and stakeholders in the technologybased media could be explained.

Table 2: The roles of communication in stakeholder theory

\begin{tabular}{ll}
\hline \multicolumn{1}{c}{ The thinkers } & \multicolumn{1}{c}{ Notion of Communication } \\
\hline Freeman (1984) & $\begin{array}{l}\text { External relation is the task of public relations, while } \\
\text { customer relations is the task of marketing. }\end{array}$ \\
\hline $\begin{array}{l}\text { Friedman dan Miles } \\
(2006)\end{array}$ & $\begin{array}{l}\text { In the stakeholder management, the roles of communication } \\
\text { are significant to realize stakeholder satisfaction. }\end{array}$ \\
\hline $\begin{array}{l}\text { Strong, Ringer \& Taylor } \\
(2001)\end{array}$ & $\begin{array}{l}\text { Communication factors mainly determine the quality of } \\
\text { stakeholder satisfaction in communicating with companies. }\end{array}$ \\
\hline Zöller (1999) & The dialog is two-way communication with stakeholders. \\
\hline Paul (2014) & $\begin{array}{l}\text { Different stakeholder interests should be managed by } \\
\text { interactive communication on the technological- } \\
\text { information-based media. }\end{array}$ \\
\hline
\end{tabular}

source: the researcher's summary

Nonetherless, Schramm (1973) speculated that communication science is the foundation of many studies about the relationship. This is because under no circumstances is a relationship not involved in communication. Although communication science should be seen as a situation that is relational or interconnective (Rogers, 1998), communication theory that explains a relationship is established in interpersonal communication. Also, although, for some cases, this could be used to explain consumer relations, given that consumer studies are individualistic, particular consideration is needed if the relations are institutional.

\section{Stakeholder Theory: Social Oriented}

"Today, it is clear that the terms of the contract between society and business are changing in substantial and important ways" (Carey, 1997).

Today, companies should understand the principle of the social contract for the sake of their existence. Companies do not live in a social vacuum. Their activities will socially affect and be affected by the community. Globalization 3.0 has breed multicultural (pluralistic), well-informed, and critical society. This society is demanding social security, recognition of human right, and real actions to preserve the environment. These are social contracts that should be concerned seriously by the company (Donaldson \& Dunfee, 1999).

Many thinkers of stakeholder theory recommend that companies should be thoughtful about the environment, and it should be justified by the environmental impact analyses and assessments (Freeman, 1984; Starik, 1994; Freedman \& Mills, 2006). Kantian thinkers (Evan \& Freeman, 1993; Bowie, 1999) even argued that companies have a fiduciary duty or obligation to act in the best interest of society. According to Blair (1998), Schlossberger (1994), and Etzioni (1998), this obligation is 
closely linked with the conception of "stakeholder as an investor" in which the company is supposed to bear mandate from the stakeholder. Likewise, in the Rawlsian theory of justice, such as Freeman (2004) and Phillps (2003), companies should firmly uphold the principle of justice in relating to the stakeholders, and it should be based on fair play concept.

Furthermore, stakeholder theory cannot be seen from the perspective of contractual, legal, and justice only, that at some point too masculine (rational). This theory should be viewed in the form of feminism by taking ethics of care that is theorized by Glligan (1982) as the underpinning. The supporters, such as Wicks, Glibert, and Freeman (1994), and Burton and Dunn (1996), stated that companies should always try to maximize stakeholder satisfaction through emotional relationship. According to Gilligan (1982), the voice of emotion and compassion are more represented in feminity (care perspective), while the discourse of masculine is more carried out by masculinity (justice perspective).

Table 3: The principle of social-oriented in Stakeholder theory

\begin{tabular}{ll}
\hline \multicolumn{1}{c}{ The thinkers } & \multicolumn{1}{c}{ The notion of social-oriented } \\
\hline $\begin{array}{l}\text { Freeman, 1984; Starik, } \\
\text { 1994; Freedman \& Mills, } \\
\text { 2006 }\end{array}$ & $\begin{array}{l}\text { Companies should care about the environment since the environment is } \\
\text { also a stakeholder (non-factor of production) that is linked with the next } \\
\text { generation (environmental perspective). }\end{array}$ \\
\hline $\begin{array}{l}\text { Evan \& Freeman, 1993; } \\
\text { Bowie, 1999 }\end{array}$ & $\begin{array}{l}\text { Companies live in the social environment, and therefore naturally have a } \\
\text { fiduciary duty or obligation to act in the best interest of society. } \\
\text { (contractual perspective) }\end{array}$ \\
\hline $\begin{array}{l}\text { Blair, 1998; Schlossberger, } \\
\text { 1994; dan Etzioni, 1998. }\end{array}$ & $\begin{array}{l}\text { Companies bear the stakeholders' mandates and, since stakeholders are } \\
\text { the investors, stakeholders' interests should be carefully considered. } \\
\text { (legal perspective) }\end{array}$ \\
\hline $\begin{array}{l}\text { Freeman, 2004; Phillips, } \\
\text { 2003 }\end{array}$ & $\begin{array}{l}\text { Considering the Rawlsian perspective grounded on the theory of justice, } \\
\text { companies should uphold the principle of justice in treating the } \\
\text { stakeholder. (Justice perspective) }\end{array}$ \\
\hline $\begin{array}{l}\text { Gilligan 1982; Burton \& } \\
\text { Dunn 1996 }\end{array}$ & $\begin{array}{l}\text { Companies should also increase stakeholder satisfaction through } \\
\text { emotional relationships. (Care perspective) }\end{array}$ \\
\hline
\end{tabular}

source: the researcher summary

Based on the perspectives above, it is clear that the primary orientation of the stakeholder theory is social. Companies cannot refuse that social interest is the government problem an sich, and as long as the companies pay the tax and follow the national rules, their business activity will succeed (Nilamsari et al., 2017; Nurjanah et al., 2017). In globalization 3.0. the people (social) should be defined altogether as consumers, workers, regulators, and journalists (social media) of the companies, and by that definition, they all are the stakeholders.

Starting from the spirit of social orientation, many thinkers formulated strategic stakeholder theory and prioritize strategy and techniques management in achieving their goals through stakeholders. Take Freeman (1984) as an example, with its idea on generic stakeholder strategy; he empathized four typologies of strategy (offensive strategy, defensive strategy, swing strategy, and hold strategy). Similarly, Savage et al. (!991) formulated the typology of stakeholder and its management strategy (supportive stakeholder, marginal stakeholder, non-supportive stakeholder dan mixed-blessing stakeholder). Mitcheel, Agle, and Wood (1997) that recommended theory on 
stakeholder identification and salience argued that stakeholders could be examined from these three attributes. Firstly, from how influential its power in affecting companies; secondly, how robust its legitimation in terms of its relationship with the companies; thirdly, how urgent its claim on the companies. Based on these three attributes, they established a stakeholder model by classifying the type of stakeholders.

Although that strategy seems not explanatory, Freedman and Mills (2006) has established concept of stakeholder engagement that is based on communication science, consisting of 12 levels of involvement, namely: manipulation therapy, information, explaining, placation, consultation, negotiation, involvement, collaboration, partnership, delegated power, and stakeholder control. That levels show that the involvement of stakeholder in the companies is started from zero-care. At this level, the company only pursues profit, as in the manipulation level. Subsequently, some extent of care is started to be given by the company, as in therapy level, and, in the next level, the company starts to contribute to stakeholders' understanding by educating them on some issues. This happens in information and explaining level. However, those four levels are still one-way communication. In the next level, placation, and consultation, the stakeholder has started to interact with the company, although it is still neutral, and there is no guarantee that their interests will be given. The higher the level, the more intensive the involvement of the stakeholder in influencing the company's objective.

\section{Stakeholder Communication: Public Relations' Perspective}

Despite stakeholder theory and the thinkers, the advocates of public relations have formulated the company communication strategy for relating with stakeholders. Indeed, in Indonesia, pubic relations explain more about stakeholders than other studies. Another relating fact is that many studies on the relationships among organizations use the conception of one-way communication (persuasive) or two-way communication (interactive), and it is implemented in many communication programs, ranging propaganda, press agentry, dissemination of information, mutual benefit, persuasion, dialogue, and co-creation, and collaboration with its variances (Grunig \& Hunt, 1984; Van Ruler, 2004; Coombs \& Holladay 2010; Capozzi \& Zipfel, 2012; Johnston \& Sheehan 2014; Gill, 2014; Angelopulo, 2015; Chauke \& du Plessis, 2015)—whether through traditional or digital media (Grunig \& Hunt, 1984; van Ruler, 2004; Duncan \& Moriarty, 1998).

Furthermore, the logic built by the advocates of public relations is similar to the notion in the stakeholder theory. It starts from one-way communication, aiming inactive stakeholder, and end with two-way communication, targetting proactive stakeholder. Although there are some differences and discussions regarding the form, methods, and type of communication at each level, the comparability is transparent.

Table 4: The comparability between public relations and stakeholder theory

\begin{tabular}{lcc}
\hline \multirow{2}{*}{$\begin{array}{c}\text { Type of } \\
\text { communication }\end{array}$} & \multicolumn{2}{c}{ STAKEHOLDER ENGAGEMENT } \\
\cline { 2 - 3 } & PUBLIC RELATIONS & STAKEHOLDER THEORY \\
\hline $\begin{array}{l}\text { One-way } \\
\text { communication }\end{array}$ & $\begin{array}{c}\text { Propaganda, Press Agentry, } \\
\text { Dissemination of Information, } \\
\text { Persuasion }\end{array}$ & $\begin{array}{c}\text { Manipulation, Therapy, Information, } \\
\text { Explaining }\end{array}$ \\
\hline
\end{tabular}




\begin{tabular}{|c|c|c|}
\hline $\begin{array}{l}\text { Two-way } \\
\text { communication }\end{array}$ & $\begin{array}{l}\text { Mutual Benefit, Dialogue, Co- } \\
\text { Creation, Collaboration }\end{array}$ & $\begin{array}{c}\text { Placation, Consultation, Negotiation, } \\
\text { Involvement, Collaboration, } \\
\text { Partnership, Delegated Power, } \\
\text { Stakeholder Control }\end{array}$ \\
\hline
\end{tabular}

source: the researcher's summary

Based on the mapping above, from the perspective of instrumental stakeholder theory, it seems identical. There are similitudes in strategy, tactic, and communication program in the stakeholder relation. However, from the perspective of normative stakeholder theory, there are fundamental differences. Two-way communication should be carried out by the company by upholding the social-oriented principle and not by strategically (operatively) managing stakeholder interest so that it is in line with companies' objectives. In public relations, the implementation of two-way communication is not based on normative-ethical aspects, which philosophically concern about the nature of companies in the social environment. Rather, it posits the company principle as a business institution that should survive in facing changes and pressure of interests from stakeholders.

The other problem regarding communication attempts to stakeholders in public relations is in one-way communication. Typically, it only represents the company objective and tends to ignore, even manipulate, stakeholder interests. One way communication is meant to be replete with meaning and content, and the purpose is to inform, educate, and build up company image. However, although it does not impinge on stakeholder interest, commonly, the communication is formulated based on the effectivity of the message only, which is operative and managerial. There is no normative-ethical basis in the company social responsibility, even though the urgency of the ethics of communication is frequently discussed, notably on the use of media and communication technology. If this notion is confronted with the basic ideas of normative stakeholder theory, the one-way communication should understand ethical caveats of communication that is in line with the ethical position of stakeholder theory.

\section{The Domain of Stakeholder Relations}

Many scientists of communication science contended that stakeholder management is a strategic function of public relations (L'Etang 2008; Doorley \& Garcia 2011; Harrison 2011; Johnston \& Sheehan 2014; Gill, 2014). Although others believed that stakeholder communication is a part of communication management, which is deemed broader than public relations (Van Ruler \& Verčič, 2004; Steyn, 2007), the majority of communication scientists, especially in Indonesia, seems to legitimate public relation to study stakeholder relations. It is not surprising if concepts of stakeholder are learned in this discipline.

However, although public relations have analyzed many types of stakeholders, not all stakeholders include in public relations' subject-matter, such as customer that is included in economical type. This understanding is in agreement with Duncan and Moriarty (1998) that stated that customer relations and brand relations are a part of marketing communication (Estaswara, 2008, 2010). Companies always strive for profit as their primary objective, and only customers are the only stakeholders that provide them with that (Estaswara, (2012). A middle way, then, needs to be considered, since the long scientific tradition of public relations does not recommend talking about customer and brand (as a stakeholder). 
As for "scientific legitimation," Goodman (2006) said that corporate communication could be used as the central concept to connect strategic communication function, such as public relations, crisis communication, corporate citizenship, reputation management, media relations, community relations, and investor relations. The problem with this idea is that it leaves a question of the role of customer relations to the company. The middle way that can be chosen regarding this discussion on the domain of stakeholder relation in communication science, public relations, organizational communication, communication management, and corporate communication is by using it alternately since the concept is reasonably identical (Grunig, 1992; Van Ruler \& Verčič, 2004; Theunissen \& Wan Noordin, 2012).

Different from the previous ideas, Hallahan et al. (2007) suggested strategic communication to explain communication in any sector, including in the company, government, and social organization. This notion is broader than the previous terminology. It can be used not only by the company, including marketing communication but also by the non-profit institution to explain their communication.

\section{The Problems of Stakeholder and the Public}

Stakeholders and the public as terms should be considered. In public relations, according to Aldoory and Grunig (2012), the public is preferred to stakeholders. The keyword of the public is mutual dependence, emphasizing relations with the company. Many academicians even said that a significant public is similar to stakeholders. Although ontologically it can be accurate in the framework of strategic-operative perspective, from the perspective stakeholder theory, the use of public as a term could make the real meaning vague and seemingly compel public relations to be wholly responsible for communication aspects in the stakeholder theory

Although the meaning (significance) behind the public and stakeholder appears similar, the name of the stakeholder inherently contains human rights principles, so that it is associated with normative-ethical (moral) understanding. A stakeholder is made of two essential words, namely stake (interest) and holder. Ontologically, a stakeholder is considerably different from the public, even though the term is modified into the significant public or mutual dependence. Stakeholders possess fundamental rights that cannot be violated. It is essential since the right of the stakeholder cannot be separated from itself. It is protected by values that, at some point, become norms and customs eventually. With this in mind, ontologically, a stakeholder is different from the term public in public relations.

\section{Reflection for Communication Science}

Stakeholder relations is a relationship among organizations, and its success is determined by communication (Bleeke \& Ernst, 1993; Mohr \& Nevin 1990; Mohr et al., 1996; L'Etang, 2008; Audi, 2009; Falconi 2010; Bovee \& Thill, 2010; Harrison, 2011; Johnston \& Sheehan, 2014; Lehman et al., 2012; Carroll \& Buchholtz, 2014; Gill, 2014). In light of the previous discussion, several recommendations appear necessary to be put forward regarding the role of communication in stakeholder relations.

Firstly, the main building blocks of stakeholder theory is in the normative-ethical aspects. Therefore, the communication strategy made should be in line with that position. It does not mean that this study should deprive or obscure the aspect of effectivity in communication (operative-managerial approach). Instead, it proposes a 
noble spirit that is established from morality and the social-oriented principle as the fundamental strategy. Stakeholder relation then requires a theoretical basis to ground normative-ethical perspective in communication science. Several theories could be used, such as social network theory, or social contract theory with the basis of the philosophy of moral of Immanuel Kant (1724-1804), John Rawls (1921-2002), or Jürgen Habermas (1929-present).

Secondly, many types of communication actions should be executed to achieve stakeholder engagement, whether that comes from stakeholder or communication thinker. Conceptual mapping about the whole steps and communication activity is needed, including media and technologies that are used, together with the effects that are produced. In this vein, communication should be the avant-garde by always analyzing the moral basis that has been theorized in stakeholder theory. Those two ideas are entangled. The first idea, which is normative-ethical, gives a soul to the second idea, which is strategic-operative. The problem is that there is no discipline in communication, including public relations, that has established stakeholder relations based on normative-ethical perspective when formulating strategy and operations.

Thirdly, formulation, and consensus in using precise terms to explain stakeholder communication. The reason is that there is no scientific consensus about this topic, notably in communication. Terminology that is often used to explain this study is stakeholder relations and stakeholder engagement. It also happens to academicians in public relations, which do not have a terminological consensus. Many academicians still use stakeholder engagement, although that concept is strategicoperative bias. Consequently, the normative-ethical perspective that should be the moral basis of stakeholder relations is undermined. The problem of using stakeholder relations, however, is that relationship theory in communication science cannot explain the relationship among institutions utterly. On the other hand, if it is explained using the perspective of public relations, it is more strategic management and strategic-operative. Not to mention that it is tainted with the problem of the significance of public and mutual dependence that cannot answer the ontology of morality in stakeholder study.

Finally, there should be an agreement in the name of the stakeholder or public. The argumentation should be scientific and philosophical and build from various theories of stakeholder theory, thus accepted by many academicians. However, ontological stakeholders cannot be juxtaposed with the significant public, mutual dependence, or even public. Those concepts have more strategic operative consequences than normative-ethical. This problem is not merely technical and operative, and therefore, can be exchanged arbitrarily. Stakeholder bears the spirit of the philosophy of moral.

\section{Conclusion}

Based on the discussion above, public relations can be said the most legitimate discipline in communication to study stakeholder relations. The problem is that the perspective of public relations is strategic management and thus being strategic operative. Also, the terms public in public relation that bears the instrumentalist perspective is unlikely to be omitted.

Stakeholder study demands normative-ethical perspective as the ground in implementing their strategy and operation. It indicates that is not only this study varied in perspectives but also a lack of moral and philosophical basis. Although public relations used to be criticized by Grunig (2009), its structure is still positivistic with 
standardization and formalization. Not to mention that Grunig (2006) also said that public relations is a profession, and therefore it is necessary to deem it as a professional discipline. Meanwhile, there is no branch in communication that is more capable of discussing stakeholder relations than public relations. Other branches, ranging from communication management, corporate communication, and strategic communication, or organizational communication, have not owned a robust scientific foundation to discuss stakeholder relations as public relations.

This study recommends that stakeholder relations be a discipline of communication science that study stakeholders using two interrelated analyses tool, normative and strategic. The most demanding homework is incorporating normativeethical aspects in stakeholder relations. That aspect should be the spirit of this study and be easy to implement. Stakeholder relations should focus on normative-ethical studies that are based on idealism (the ought to). For the aspect of strategic-operative that is closer to realism can be delegated to public relations, organizational communication, corporate communication, strategic communication, and communication management. With the above in mind, stakeholder relation can be present as a study that has a normative-ethical and non-positivist perspective (post-modernist/post-positivist). Also, it should become intelligent control of strategic-operative studies that focus on stakeholder management to achieve company objectives.

\section{References}

Aldoory, L. \& Grunig, J. (2012). The Rise and Fall of Hot-Issue Publics: Relationships that Develop From Media Coverage of Events and Crises. International Journal of Strategic Communication, Vol. 6(1), 93-108.

Almadani, A. (2014). Globalization and Corporate Governance. International Journal of Innovation, Management, and Technology, Vol. 5(5), 394-400.

Angelopulo, G. (2015). Communication integration. Dalam G. Angelopulo \& R. Barker (eds.), Integrated Organisational Communication. Cape Town: Juta \& Co, 40-71.

Arshed, N., \& Danson, M. (2015). The Literature Review. Dalam K. O'Gorman\&M. MacIntosh (eds.). Research Methods for Business \& Management.2nd ed. Oxford: Goodfellow Publishers Limited, 31-49.

Audi, R. (2009). Business Ethics and Ethical Business. NY: Oxford University Press.

Burhan, A.B., \& Estaswara, H. (2012), Linearitas Pergeseran Pemikiran Marketingdan Komunikasi Berdasarkan Perkembangan Teknologi Media. CoverAge: Journal of Strategic Communication, Vol. 3(1), 68-74.

Blair, M.M. (1998). Whose Interests Should Corporations Serve? Dalam M.B.E. Clarkson (ed.), The Corporation and Its Stakeholders: Classic and Contemporary Reading. Toronto: University of Toronto Press.

Bourne, L. (2015). The three types of stakeholder communication. PM World Journal, Vol. 4(9), 1-5.

Bovee, C.L. \& Thill, J.V. (2010). Business Communication Today. 10th Ed. New Jersey: Pearson.

Bowie, N.E. (1999). Business Ethics: A Kantian Perspective. Oxford: Blackwell.

Burton, B.K. \& Dunn, C.P. (1996). Feminist Ethics as Moral Grounding for Stakeholder Theory. Business Ethics Quarterly, Vol. 6(2), 133-147.

Carrol, A.B. \& Buchholtz, A.K. (2014). Business \& Society: Ethics and Stakeholder Management. 9th Ed. USA: South-Western Cengage Learning. 
Carey, J. “The Tobacco Deal: Not So Fast,” Business Week, 7 Juli 1997.

Chauke, G. \& du Plessis, D. (2015). Public relations. Dalam G. Angelopulo \& R. Barker (eds.), Integrated Organisational Communication. Cape Town: Juta \& Co, 222-5.

Cannon, J.P. \& Perreault, W.D., Jr. (1999). Buyer-seller relationships in business markets. Journal of Marketing Research, Vol. 36(4), 439-460.

Coombs, W.T. \& Holladay, S. (2010). PR Strategy and Application: Managing Influence. New Jersey: Wiley-Blackwell.

Creswell, J.W. (2014). Research design: Qualitative and quantitative approaches. 4th ed. Thousand Oaks, CA: Sage Publication.

Davis, K. \& Blomstrom, R.L. (1966). Business and Society: Environment and Responsibility. 3rd Ed. New York: McGraw-Hill.

Denney, A.S., \& Tewksbury, R. (2012). How to Write a Literature Review. Journal of Criminal Justice Education, Vol. 24(2), 218-234.

Duncan, T. \& Moriarty, S. (1998). A communication-based marketing model for managing relationships.Journal of Marketing, Vol. 62(2), 1-13.

Donaldson, T., \& Preston, L.E. (1995). The Stakeholder Theory of the Corporation: Concepts, Evidence, and Implications. The Academy of Management Review, Vol. 20(1), 65-91.

Donaldson, T. \& Dunfee, T.W. (1999). Ties That Bind: A Social Contracts Approach to Business Ethics. Cambridge, MA: Harvard Business School Press.

Estaswara, H. (2008), Think IMC: Efektivitas Komunikasi untuk Meningkatkan Loyalitas Merek dan Laba Perusahaan. Jakarta: Gramedia Putaka Utama.

Estaswara, H. (2010). Stakeholder relationships in Integrated Marketing Communications (IMC): A theoretical perspective. Journal of Strategic Communication, 1(1), 61-75.

Estaswara, H. (2011a), Corporate Cyber-Crisis: A Case Study of Omni International In Indonesia. Journal of Modern Accounting \& Auditing, Vol. 7(8), 878-890.

Estaswara, H. (2011b), "Computer-Mediated Public Sphere," and Stakeholder Relationships Model. International Journal of Arts \& Sciences. CD-ROM. ISSN: 1944-6934, Vol. 4(7), 99-112.

Estaswara, H. (2012), Brand management mapping: An integrated marketing communications (IMC) perspective. Dalam N. Sarasnatiti, F. Lengkong, \&M. Sintawati (Eds.), Enterpreneurship in Global Competition. Jakarta: Universitas Atmajaya Publication, 419-436.

Estaswara, H. (2015). Integrated Marketing Communications (IMC): Extended Version or New Idea? Journal of Global Academic Institute Education \& Social Sciences (JGAIESS), Vol. 1(2), 123-139.

Estaswara, H. (2016). Integrated Marketing Communication (IMC) in Higher Education in Indonesia. Polish Journal of Management Studies (PJMS), Vol. 14(1), 74-83.

Evan, W.M., \& Freeman, R.E. (1993). A Stakeholder Theory of the Modern Corporation: Kantian Capitalism. Dalam T.L. Beauchamp \&N.E. Bowie (eds.), Ethical Theory and Business. Englewood Cliffs, NJ: Prentice-Hall, 75-84.

Etzioni, A. (1998). A Communitarian Note on Stakeholder Theory. Business Ethics Quarterly, Vol. 8(4), 679-691.

Freeman, R.E. (1984). Strategic Management: A Stakeholder Approach. Marshfield, MA: Pitman. 
Freeman, R.E. (2004). A Stakeholder Theory of the Modern Corporation. Dalam T.L. Beauchamp \&N.E. Bowie (eds.), Ethical Theory and Business, 7th ed. Upper Saddle River, NJ: Pearson/Prentice-Hall, 55-64.

Freeman, R. E., Harrison, J. S., Wicks, A. C, Parmar, B., \& de Colle, S. (2010). Stakeholder theory: The state of the art. Cambridge: Cambridge University Press.

Friedman, A.L. \& Miles, S. (2002). Developing Stakeholder Theory. Journal of Management Studies, Vol (1), 1-21.

Friedman, A.L. \& Miles, S. (2006). Stakeholders: Theory and Practice. Oxford University Press.

Gilligan, C. (1982). In a Different Voice. Cambridge. MA: Harvard University Press.

Gill, R. (2014). Public Relations and the New Stakeholder Management Environment. International Journal of Academic Research in Business and Social Sciences, Vol. 4(10), 100-107.

Goodman, M.B. (2006). Corporate Communication Practice and Pedagogy at the Dawn of the New Millenium. Corporate Communication: An International Journal, Vol. 11(3), 196-213.

Grunig, J.E. (1992). Excellence in public relations and communication management. New Jersey: Lawrence Erlbaum Associates.

Grunig, J.E. (2008). Excellence Theoryin public relations dalam The International Encyclopedia of Communication. Donsbach, W (ed)., Blackwell Publishing. DOI:10.1002/9781405186407.wbiece047

Grunig, J. E. (2009). Paradigms of global public relations in an age of digitalisation. Prism, Vol. 6(2). http://praxis.massey.ac.nz/prism_on-line_journ.html.

Grunig, J. E. (2006). Research in Public Relations: Current Status and New Directions. Anàlisi, Vol. 34: 49-65.

Grunig, J.E. \& Hunt, T. (1984). Managing Public Relations. New York: Holt, Rinehart, and Winston.

Hallahan, K., Holtzhausen, D., van Ruler, B., Verčič, D., \& Sriramesh, K. (2007). Defining strategic communication. International Journal of Strategic Communication. Vol. 1(1), 3-35.

Harrison, K. (2011). Strategic Public Relations: A practical guide to success. Melbourne: Palgrave McMillan.

Hart, C. (2018). Doing a literature review: Releasing the social science research imagination. 2nd ed. London, UK: Sage Publications.

Johnston, J., \& Sheehan, M. (2014). Theory and Practice Public Relations. 4th Ed. Crows Nest NSW: Allen \& Unwin.

L'Etang, J. (2008). Public Relations Concepts, Practice and Critique. London: Sage.

Lehman, C., Dufrene, D., Cameron-Dow, J., Barret, M. \& Murphy, W. (2012). BCOM. AsiaPacific Edition. South Melbourne: Cenage Learning.

Marshall, C., \& Rossman, G.B., (2015). Designing qualitative research. 7th Ed. Newbury Park, CA: Sage Publication.

Mohr, J.J., Fisher. R.J. \& Nevin, J.R. (1996). Collaborative communication in interfirm relationships: moderating effects of integration and control. Journal of Marketing, Vol. 60(3), 103-115.

Morsing, M., \& Schultz, M. (2006). Corporate social responsibility communication: Stakeholder information, response, and involvement strategies. Business Ethics: A European Review, Vol. 15(4), 323-338. 
Natalina Nilamsari, N., Saleh, A., Hubeis, M., \& Pandjaitan, N. K. (2017). Komunikasi Corporate Social Responsibility Untuk Pemberdayaan Peternak Sapi Perah, Jurnal ASPIKOM, Vol. 3(2), 296-310.

Nurjannah, Suwanto, \& Damayanti, W. (2017). Komunikasi Corporate Social Responsibility Pada Official Website Perusahaan Badan Usaha Milik Negara, Jurnal ASPIKOM, Vol. 3(2), 311-325.

Paul, K. (2014). Stakeholder Theory, Meet Communications Theory: Media Systems Dependency and Community Infrastructure Theory, with an Application to California's Cannabis/Marijuana Industry. Journal of Business Ethics. DOI: 10.1007/s10551-014-2168-x.

Phillips, R. (2003). Stakeholder Legitimacy. Business Ethics Quarterly, Vol. 13(1), 2541.

Rogers, L.E. (1998) The meaning of relationship in relational communication. Dalam R.L. Conville \& L.E. Rogers (Eds.), The meaning of "relationship" in interpersonal communication. Westport, CT: Praeger, 69-81.

Savage, G.T., Nix, T.W., Whitehead, C.J., \& Blair, J.D. (1991). Strategies for Assessing and Managing Organizational Stakeholders. Academy of Management Executive, Vol. 5(2), 61-75.

Schramm, W. (1973). Men, messages, and media; a look at human communication. New York: Harper \& Row.

Schlossberger, E. (1994). A New Model of Business: Dual-Investor Theory. Business Ethics Quarterly, Vol. 4(4), 459-474.

Stainer, L. (2004). Ethical Dimensions of Management Decision-making, Strategic Change, Vol. 13(6), 333-342.

Starik, M. (1994). Essay by Mark Starik: The Toronto Conference: Reflections on Stakeholder Theory. Business \& Society, Vol. 33(1), 89-95.

Steyn, B. (2007). Contribution of Public Relations to Organizational Strategy Formulation. Dalam E. L. Toth, ed. The Future of Excellence in Public Relations and Communication Management: Challenges for the Next Generation. Mahwah, NJ: Lawrence Erlbaum, 158-166.

Strong, K.C., Ringer, R.C., \& Taylor, S.A. (2001). The Rules of Stakeholder Satisfaction (Timeliness, Honesty, Empathy). Journal of Business Ethics, Vol. 32(3), 219-230.

Theunissen, P. \& Wan Noordin, W.N. (2012). Revisiting the concept 'dialogue' in public relations. Public Relations Review, Vol. 38(1), 5-13.

Van Ruler, B. (2004). The communication grid: an introduction of a model of four communication strategies. Public Relations Review, Vol. 30(2), 123-143.

Van Ruler, B.,\& Verčič, D. (2004). Public Relations and Communication Management in Europe: A Nation-by-Nation Introduction To Public Relations Theory and Practice. Berlin: Mouton de Gruyter.

Webster, J., \& Watson, R.T. (2002). Analyzing the past to prepare for the future: Writing a literature review. MIS Quarterly, Vol. 26(2), 13-23.

Wick, A.C., Gilbert, D.R., Jr., \& Freeman, R.E. (1994). A Feminist Reinterpretation of the Stakeholder Concept. Business Ethics Quarterly, Vol. 4(4), 475-497.

Zöller, K. (1999). Growing Credibility Through Dialogue: Experiences in Germany and the USA. Dalam M. Charter \& M. J. Polonsky (eds.), Greener Marketing: A Global Perspective on Greening Marketing Practice. Sheffield, UK: Greenleaf Publishing, 196-206. 